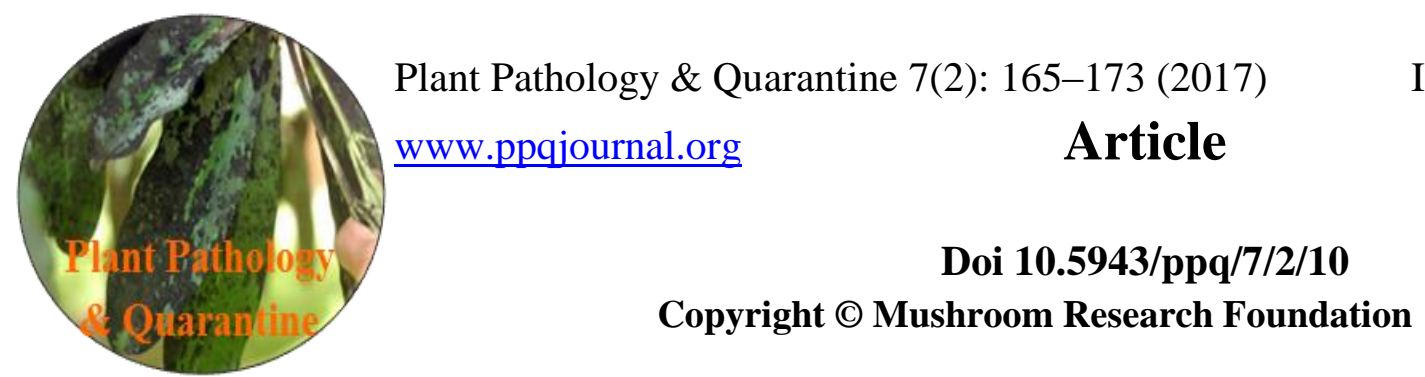

\title{
Karnal bunt of wheat in India and its management: a review
}

\author{
Sharma $\mathbf{A}^{1^{*}}$, Sharma $\mathbf{P}^{1}$, Dixit $\mathbf{A}^{2}$ and Tyagi $\mathbf{R}^{3}$ \\ ${ }^{1}$ Department of Zoology, Stani Memorial PG College, Jaipur-302020, India \\ ${ }^{2}$ Department of Zoology, St. Xavier's College, Nevta, Jaipur-302029, India \\ ${ }^{3}$ Department of Biotechnology, Suresh Gyan Vihar University, Jaipur-302017, India
}

Sharma A, Sharma P, Dixit A, Tyagi R 2017 - Karnal bunt of wheat in India and its management: a review. Plant Pathology \& Quarantine 7(2), 165-173, Doi 10.5943/ppq/7/2/10

\begin{abstract}
Wheat has been a source of staple food to mankind since ancient times. Decreased production of wheat in the major wheat growing countries may be attributed to prevalence of Karnal bunt disease. The major impact of Karnal bunt is yield reduction and a decrease in quality of grains by imparting a fishy odour and taste to the wheat. The disease has gained significant importance due to the fact that it is prevalent only in a few countries around the world. The pathogen Tilletia indica is soil and seed borne which pose a serious quarantine problem and thus interferes with wheat trade. Early recognition of the pathogen is a critical step in analysis and its management. The present review highlights a brief outline of the pathogen, symptoms and various methods like seed treatment, crop rotation, fungicide application etc. for the control of Karnal bunt disease.
\end{abstract}

Keywords - disease - fungicide - pathogen - Tilletia indica - quarantine

\section{Introduction}

Agriculture plays a vital role in the economy and stability of India. Wheat (Triticum aestivum) is one of the most important food crops of the world. Although as many as 25 species of wheat have been recognized, only three species are commercially grown in India namely $T$. aestivum /vulgare (bread wheat), T. durum (macaroni wheat) and $T$. dicoccum (emmer wheat). Wheat is primarily a rabi (winter) crop, and production is highly concentrated in the northern belt of Uttar Pradesh, Punjab, and Haryana, which together contribute 67\% of total production and 55\% of area (Joshi et al. 2007, Singh \& Gogoi 2011).

Wheat is grown throughout the world with an annual production more than 600 million tonnes. Production of wheat must continue to increase annually by $2 \%$ to meet future demands imposed by population and prosperity growth. This challenge will probably be further compounded by increased temperature due to global warming (Fischer et al. 2002), reduced water availability, new races of pathogens and pests besides decrease in public sector investment in rural affairs and agriculture (Falcon \& Naylor 2005).

Wheat is the dominant crop used for human food and livestock feed in temperate countries. A wide range of products are now made and consumed worldwide from wheat. The key feature which has given it an advantage over other temperate crops is the unique properties of dough formed from wheat flours, which allow it to be processed into a range of breads and other baked products, pasta,

Submitted 23 September 2017, Accepted 8 October 2017, Published 28 November 2017 
noodles, and other processed foods. These properties depend on the structures and interactions of the grain storage proteins, which together form the 'gluten' protein fraction (Shewry 2009).

In India, wheat is affected by various diseases such as rusts, powdery mildew, loose smut, leaf blight and Karnal bunt (Juroszek \& Tiedemann 2013). Amongst these, Karnal bunt is the major disease of wheat and caused by the fungus, Tilletia indica (syn Neovosia indica). It is the limiting factor in increasing wheat yield (Aggarwal et al. 2008, Kumar et al. 2008, Shakoor et al. 2008, Sharma et al. 2011).

\section{Karnal bunt}

Karnal bunt was first reported by Mitra (1931) from Karnal, a place now in Haryana state of India from where the name Karnal originates. Karnal bunt is also known as partial bunt. Earlier it was a minor disease found only in Northwestern India. During the 1969-70 crop seasons it was unusually widespread in Northwest India and since 1974-75 Karnal bunt has been distributed throughout Northern India from West Bengal to the western border. The disease has been reported to occur in many parts of the world such as Pakistan, Nepal, Iraq, Iran, Afghanistan and Mexico. The development and wide distribution of wheat cultivars that were more susceptible may increase geographic distribution of Karnal bunt. Several Indian wheat varieties have been reported to be resistant against Karnal bunt but most cultivars are susceptible (Haq et al. 2002, Carris et al. 2006).

Karnal bunt is a limiting factor in wheat export because the pathogen is regulated by most countries as a quarantine pest. As a seed borne pathogen it threatens wheat trade between countries. Therefore, it has significance in seed certification aspects (Kumar et al. 2008, Tan et al. 2009, 2010).

Karnal bunt pathogen is seed-, soil- and air-borne. It affects mainly common wheat, durum wheat, triticale and other related species. The disease reduces seed quality, changes the chemical composition of infected grains, and makes seed inedible. Wheat containing $3 \%$ bunted grains is unfit for human consumption (Ullah et al. 2012). Highly infected grains show remarkable decrease in the seed viability. Increase in grades of infection leads to continuous decrease in fertility. The disease is characterized by a fishy odour, which is due to the presence of trimethylamine secreted by teliospores.

\section{Pathogen}

Mitra (1931) reported the causal organism of Karnal bunt as Tilletia indica but later Mundkur (1940) renamed it as Neovossia indica. Genus Tilletia, belongs to family Tilletiaceae, order Ustilaginales, class Basidiomycotina. The pathogen has a restricted distribution, being limited largely to the Indian subcontinent and a small area of Mexico and the south-western United States of America. The pathogen is heterothallic and undergoes sexual reproduction after teliospore germination. Primary and secondary sporidia or hyphae as compatible mating types must fuse to form a dikaryon which enhances the chances of variation due to heterozygosity that plays a significant role in the production of new variants (Jones 2009).

Five pathogenic populations viz. KBAg-1, KBAg-2, KBAg-3, KBAg-4 and KBAg-5 are known to exist in $T$. indica. The teliospores of these pathotypes can be divided into three broad groups on the basis of arrangement of surface rodlets: (i) rodlets compact and regular, (ii) rodlets loose and irregular, and (iii) exines very loose and irregular. KBAg-2 is the most virulent and contains highest contents of lipids, protein, sugars, and nitrogen and also has linolenic acid while the less aggressive isolate KBAg-6 has lesser amount of these constituents and does not have carpic acid and pentadecenoic acid. All pathotypes revealed different $R_{\mathrm{f}}$ values in polyacrylamide gel electrophoresis (PAGE) analysis (Ahlawat 2007).

The pathogen infects the ovaries in the growing wheat heads and converts all or part of the wheat seed into a black powder consisting of millions of teliospores (Singh et al. 2012, Muhammad et al. 2013). The major impact of Karnal bunt of wheat is on quality and not on reduction. Infected 
seeds are the most important carrier of pathogens for trans-regional and long-distance dispersal of the spores (Parveen et al. 2013).

\section{Detection}

Detection of wheat pathogens is based primarily on conventional methods such as direct inspection of dry seeds, washing test, soaking test, incubation tests, blotter tests, embryo count test and filter and centrifuge extraction technique (Tan et al. 2013). These methods were in regular practice till late in the $20^{\text {th }}$ century. Molecular approaches (Lopez et al. 2003), which are specific, fast, active and determined, were developed for accurate and rapid detection of seed borne pathogens. Molecular diagnostic techniques have been developed after the introduction of PCR in the mid 1980s for major seed borne diseases of wheat. Genomic techniques for characterization of plant pathogens during the past decades has greatly simplified and improved pathogen detection and identification (McDonald 2000, McNeil et al. 2004). PCR-based assays are generally used for species specific detection of Fusarium culmorum, $F$. graminearum and $F$. avenaceum from contaminated seeds (Kumar et al. 2006). Detection through real-time PCR was reported for fungal species (Waalwijk et al. 2004, Majumder et al. 2013).

\section{Future risk of $\boldsymbol{T}$. indica infection}

Large fields of wheat in the European and Mediterranean region are at a high risk of infection by $T$. indica. Wheat grown in a semi-arid environment of Australia is also deemed to be at risk (Sansford et al. 2008, Stansbury \& McKirdy 2002).

\section{Epidemiology of $T$. indica}

Development of Karnal bunt depends on the availability of favorable conditions for infection and disease development from heading to flowering (anthesis) of the wheat crop. Progression of disease is favoured by moderate temperatures, high relative humidity or free moisture, cloudiness, and rainfall during anthesis. There is a range of conflicting information available on how abiotic conditions during the rest of the year affect survival of the pathogen and development of Karnal bunt (Stein et al. 2005).

\section{Symptoms}

Karnal bunt is mainly a disease related to grains. Either in partially or fully infected condition the whole grain is converted into black powder of bunt spores. In highly infected spikelets, bunted grains form a greater angle with the main axis (Figs 1,2) and may fall to the ground. At the beginning, the smut sorus is covered with a membrane (pericarp) which, when it bursts, releases black masses of spores that contribute to the bunt smell. The spores may disperse with air or may fall to the ground and thus the inoculum is not limited to only fields but can spread to distant places (Goates \& Jackson 2006).

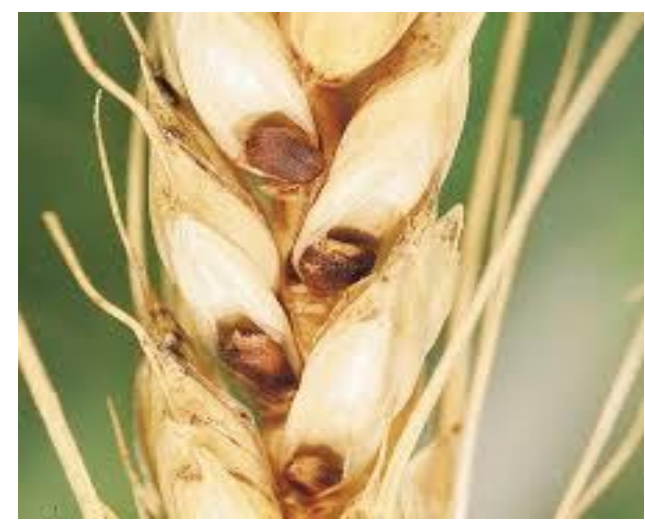

Fig. 1 - Common bunt in wheat showing glumes containing bunt balls 


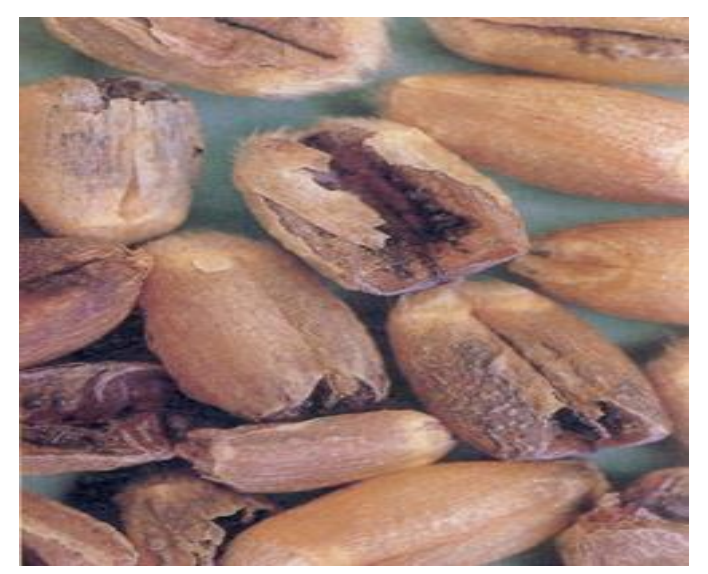

Fig. 2 - Bunt infected wheat seeds appear greyish brown with soot-like spores inside

\section{Disease cycle}

Karnal bunt was reported as a soil borne disease by Mitra (1931), but now it is considered as an air borne disease. The fungal spores are also transferred by means of equipment, tools or by man moving from milling places. The spores remain viable for several years in soil (Bonde et al. 2004), wheat straw and farm yard manure. Soil or seeds are primary sources of inoculum (Fig. 3). Environment plays a key role in disease progression. Teliospores germinate at suitable temperature $\left(15-25^{\circ} \mathrm{C}\right)$ and humidity in the soil. This condition generally dominates during February to March in North Indian plains (Dumalasová \& Bartoš 2009, Rush et al. 2005).

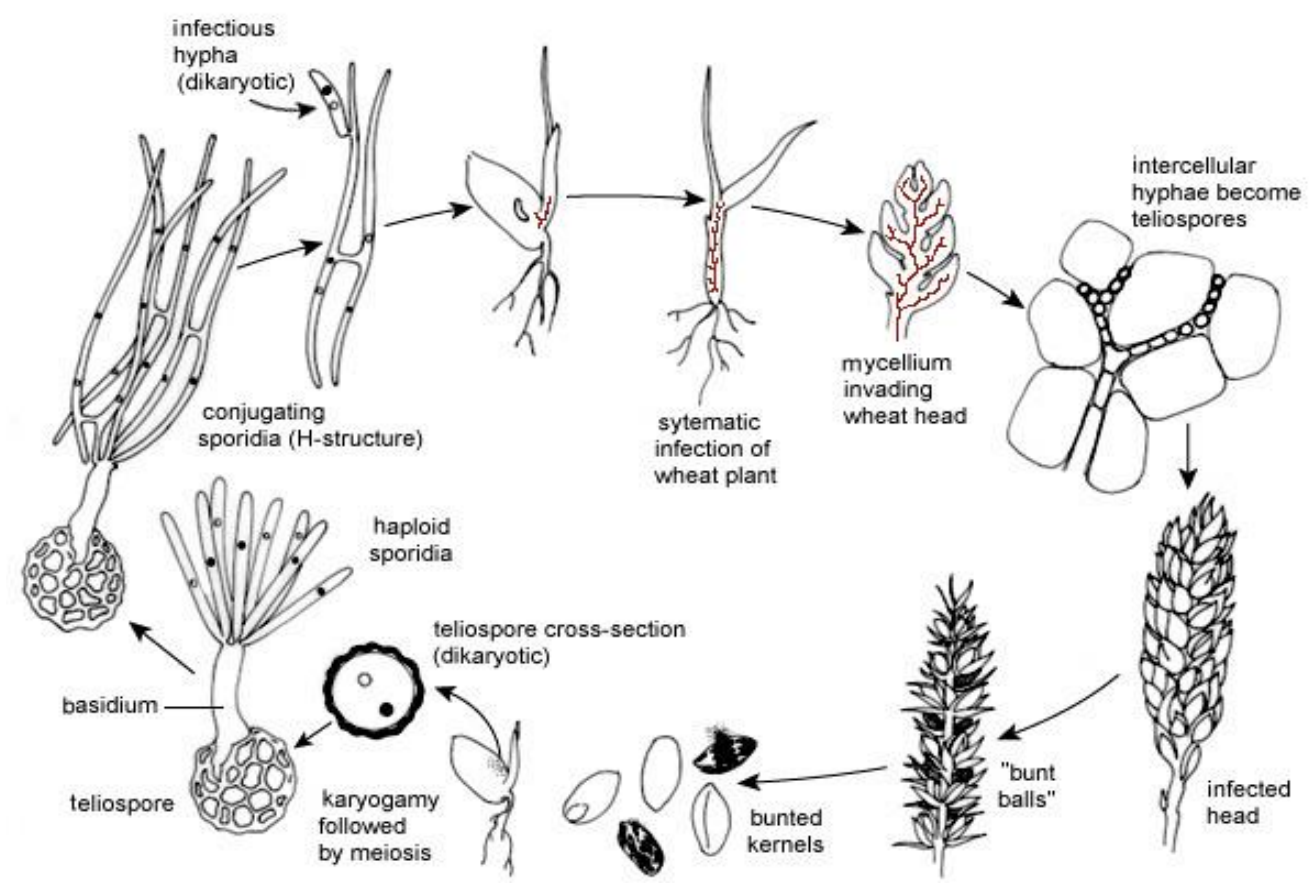

Fig. 3 - Disease cycle of the pathogen

On germination, each teliospore produces promycelium which bears 110-185 primary sporidia at its tip. The primary sporidia are sickle shaped and were regarded as infective entities. Now it is well known that secondary sporidia (allantoid and filiform) play an important role in the disease cycle of the pathogen. The allantoid sporidia are pathogenic while filiform sporidia increase the inoculum by division on host/soil surface. The sporidia are mostly binucleate and on 
germination produce a germ-tube that penetrates the developing grain through stigma or ovary wall. Infection takes place mainly at the time of anthesis. Generally, the grains are moderately affected but in severe conditions whole grain may be infected (Carris et al. 2006, Castlebury et al. 2005, Inman et al. 2008).

\section{Control}

Karnal bunt is difficult to control due to its intermittent nature. The prevalence of Karnal bunt changes considerably from year to year depending on availability of favorable conditions during heading. As the spores can remain viable in the soil for a considerable period so it is very difficult to eliminate the fungus. Significant loss in quality and quantity generally arises in wheat fields having high inoculum density. Therefore, quarantine restriction is applied by approximately 70 countries on wheat trade where Karnal bunt is known to occur (Kumar et al. 2015, Kumar \& Singh 2014).

The measures to control Karnal bunt in the field are:

\section{Resistant varieties}

Use of resistant varieties is the most effective method for controlling the disease. Among recent wheat varieties, PBW 502 is resistant while the cultivars Pastour, N-75-3 and N-75-5 are partially resistant. Some lines of wheat and allied genera (Aegilops) were found to be resistant to bunt and this resistance can be manipulated for transferring into bread wheat (Jafari et al. 2000, Ullah et al. 2012).

\section{Seed treatment}

Many viable spores on the seed can be eliminated by seed treatment but do not protect wheat plants from infection if the seed are planted in infected soil. Seed treatment with fungicide is not effective for removal of complete infection, as the fungus is soil borne, but it may minimize the chances of infection (El-Naimi et al. 2000).

\section{Fungicide seed treatment}

This method has been used to reduce the spread of inoculum via seed, however, there are only a few fungicides currently registered for use against bunts. Hexachlorobenzene and cyano (methylmercuric) guanidine prevented germination of teliospores of $T$. indica. A number of chemical companies are seeking to register fungicides such as PCNB and carboxin + thiram (Vitavax 200 or RTU-Vitavax-Thiram) for use against Karnal bunt since they have shown to restrict the germination of seed borne spores in Mexico (Joshi et al. 1983). The main problem of using current fungicides is that Karnal bunt spores may germinate when the chemical is washed off the spore (Sharma \& Basandrai 2000).

\section{Fungicide foliar treatment}

Applying fungicides on a routine basis is often cost prohibitive. The incidence of Karnal bunt can be effectively reduced by the application of foliar fungicides between late boot and flowering. Some effective fungicides are Propioconazole, Agrozim and Bavistin (carbendazim) and Bayleton (triadimefon). Foliar spray by fungicide, propiconazole (Tilt 25EC20.1\%) should be given at the time of anthesis as the disease is air borne. It is less expensive and an environment friendly method for the control of Karnal bunt of wheat (Kumar \& Singh 2014).

\section{Soil fumigation}

Fumigation of soil with chemicals such as methyl bromide, metham-sodium and formaldehyde has been partially successful for killing teliospores, but is not likely to be cost effective except for eradicating a new introduction of fungus (Sharma \& Kumar 2017). 


\section{Bio-control agents}

Integration of propiconazole with bioagent fungus (Trichoderma viride) gives almost complete control. The bioagent spray should be done before ear head emergence followed by spray of chemical at start of ear head emergence (Sharma \& Basandrai 2000).

\section{Crop rotation}

Crop rotation is also useful in managing the disease. The number of viable teliospores in the soil can be reduced by increasing the time between wheat crops. Rotation with non-host crops may reduce viable spores sufficiently to control the disease (Sharma et al. 2004). Crop rotations should always be considered when cropping decisions are made as it provides many benefits in addition to disease control (Porter et al. 2003, Brooks 2011).

\section{Mulching}

The temperature of the soil rises considerably by practices of polythene mulching and wheat straw burning after mechanical harvesting. Polyethylene mulching increased the soil surface temperature to $54.5^{\circ} \mathrm{C}$ and straw burning raised the temperature of the soil surface, $5 \mathrm{~cm}$ and $10 \mathrm{~cm}$ depth of soil to $92.5^{\circ} \mathrm{C}, 67.0^{\circ} \mathrm{C}$ and $58.0^{\circ} \mathrm{C}$, respectively, and enabled the soil to be disinfected from the bunt propagules (Wright et al. 2006).

\section{Controlled irrigation}

Controlling irrigation at the time of heading and flowering, deep plowing, and planting cover crops will help in minimizing Karnal bunt disease (Stansbury \& Pretorius 2001). Farmers may need to consider altering irrigation schedules that develop suitable climatic conditions for restricted development and spread of $T$. indica.

\section{Changing sowing time}

Karnal bunt disease can also be managed by avoiding sowing of highly susceptible cultivars in the endemic areas. In some places, changing the sowing time may alter flowering to less favorable conditions for infection (Wright et al. 2006).

\section{Conclusion}

Karnal bunt is a serious disease because of its influence on global trade of wheat grains. Karnal bunt has potentially serious phytosanitary implications for wheat production and agricultural trade in some countries. To achieve effective management of this disease, continuous efforts of scientists and regulators are required. The development of more adaptable, powerful and profitable systems will continue over the coming years, which allow greater sensitivity and selectivity for elevated throughput and detection of multiple microbes. The Indian Department of Agriculture has applied control measures in the contaminated areas to limit its spread. The management of Karnal bunt disease can be done by encouraging farmers for cultivation of bunt resistant varieties, discouraging broadcasting of seed to reduce the impact of germination of primary inoculums from infected seed material and by mass campaigning for use of fungicide in Karnal bunt sensitive area.

\section{References}

Aggarwal R, Srinivas P, Srivastava KD, Singh DV. 2008 - Soil borne diseases of wheat and their management. In: Naik, Rani D (eds) Advances in Soil Borne Plant Diseases. New India Publishing Agency, New Delhi,165-217.

Ahlawat YS. 2007 - Crop Diseases and their Management. Plant Pathology, Division of Plant Pathology, Indian Agricultural Research Institute, New Delhi, 1-98. 
Bonde MR, Nester SE, Olsen MW, Berner DK. 2004 - Survival of teliospores of T. indica in Arizona field soils. Plant Disease 88, 804-810.

Brooks SA. 2011 - Influences from long-term crop rotation, soil tillage, and fertility on the severity of rice grain smuts. Plant Disease 95, 990-996.

Carris LM, Castlebury LA, Goates BJ. 2006 - Nonsystemic bunt fungi-T. indica and T. horrida, a review of history, systematics, and biology. Annual Review of Phytopathology 44, 113-133.

Castlebury LA, Carris LM, Vanky K. 2005 - Phylogenetic analysis of Tilletia and allied genera in order Tilletiales (Ustilaginomycetes; Exobasidiomycetidae) based on large subunit nuclear rDNA sequences. Mycologia 97, 888-900.

Dumalasová V, Bartoš P. 2009 - Will climatic changes enhance the risk of T. indica in Europe? Plant Protection Science 45, S38-S40.

El-Naimi M, Toubia-Rahme H, Mamluk OF. 2000 - Organic seed treatment as a substitute for chemical seed treatment to control common bunt of wheat. European Journal of Plant Pathology 106, 433-437.

Falcon WP, Naylor RL. 2005 - Rethinking food security for the 21st century. American Journal of Agricultural Economics 87(5), 1113-1127.

Fischer G, Shah M, van Velthuizen H. 2002 - Climate change and agricultural vulnerability. World Summit on Sustainable Development, Johannesburg.

Goates BJ, Jackson EW. 2006 - Susceptibility of wheat to T. indica during stages of spike development. Phytopathology 96, 962-966.

Haq EU, Rattu AR, Mirza JI. 2002 - Prevalence of Karnal bunt of wheat in KPK (Pakistan). International Journal of Agriculture and Biology 4, 150-152.

Inman A, Magnus HA, Riccioni L, Hughes K, Coates M, Barnes A, Barton V, Sansford CE, Valvassori M, Di Giambattista G, Porta-Puglia A, Razzaghian J, Peterson GL. 2008 Survival of Tilletia indica teliospores under European soil conditions. Plant Pathology 57, 290-300.

Jafari H, Torabi M, Alizadeh A. 2000 - Evaluation of resistance of some advanced cultivars/lines of wheat to T. indica, the causal organism of Karnal bunt. Seed and Plant 15, 296-312.

Jones DR. 2009. Towards a more reasoned assessment of the threat to wheat crops from T. indica, the cause of Karnal bunt disease. European Journal of Plant Pathology 123, 247-259.

Joshi AK, Mishra B, Chatrath R, Ortiz Ferrara G, Singh RP. 2007 - Wheat improvement in India: present status, emerging challenges and future prospects. Euphytica 157, 431-446.

Joshi LM, Singh DV, Srivastava KD, Wilcoxson RD. 1983 - Karnal bunt: a minor disease that is now a threat to wheat. The Botanical Review 49, 309-330.

Juroszek P, Tiedemann AV. 2013 - Climate change and potential future risks through wheat diseases: a review. European Journal of Plant Pathology 136, 21-33.

Kumar A, Gupta A, Atwal SS, Maheshwari VK, Singh CB. 2015 - Post-harvest management of Karnal bunt, a quarantine disease in wheat. Plant Pathology 14, 23-30.

Kumar A, Singh US, Kumar J, Garg GK. 2008 - Application of molecular and immune diagnostic tools for detection, surveillance and quarantine regulation of Karnal bunt (T. indica) of wheat. Food and Agricultural Immunology 19, 293-311.

Kumar M, Luthra OP, Chawla V, Chaudhary L, Saini N, Poonia A, Kumar R, Singh AP. 2006 Identification of RAPD markers linked to the Karnal bunt resistance genes in wheat. Biologia Plantarum 50, 755-758.

Kumar S, Singh D. 2014 - Integrated management of Karnal bunt of wheat. Journal of Industrial Pollution Control 30, 247-250.

Lopez MM, Bertolini E, Olmos A, Caruso P, Gorris MT, Llop P, Penyalver R, Cambra M. 2003 Innovative tools for detection of plant pathogenic viruses and bacteria. International Microbiology 6, 233-243.

Majumder D, Rajesh T, Suting EG, Debbarma A. 2013 - Detection of seed borne pathogens in wheat: recent trends. Australian Journal of Crop Science 7, 500-507. 
McDonald JG. 2000 - Differentiation of Tilletia species by rep-PCR genomic fingerprinting. Plant Diseases 84, 1121-1125.

McNeil M, Roberts AMI, Cockerell V, Mulholland V. 2004 - Real-time PCR assay for quantification of $T$. caries contamination of UK wheat seed. Plant Pathology 53, 741-750.

Mitra M. 1931 - A new bunt on wheat in India. Annals of Applied Biology 18, 178-179.

Muhammad A, Muhammad R, Muhammad S, Aftab B, Muhammad I. 2013 - Response of some commercial cultivars and advanced lines of wheat against Karnal bunt of wheat and its management through chemicals. International Journal of Plant Research 3, 47-51.

Mundkur BB. 1940 - A second contribution towards knowledge of Indian Ustilaginales. Transactions of the British Mycological Society 24, 312-336.

Parveen S, Saharan MS, Verma A, Sharma I. 2013 - Comparative analysis of RAPD and ISSR marker assays for detecting genetic polymorphism in $T$. indica. European Journal of Plant Pathology 3, 380-387.

Porter PM, Huggins DR, Perillo CA, Quiring SR, Crookston RK. 2003 - Organic and other management strategies with two- and four-year crop rotations in Minnesota. Agronomy Journal 95, 233-244.

Rush CM, Stein JM, Bowden RL, Riemenschneider R, Boratynski T, Royer MH. 2005 - Status of Karnal bunt of wheat in the United States 1996 to 2004. Plant Disease 89, 212-223.

Sansford CE, Baker RHZ, Brennan JP, Ewert F, Gioli B, Inman A, Kinsella A, Magnus HA, Miglietta F, Murray GM, Porta-Puglia A, Porter JR, Rafoss T, Riccioni L, Thorne F. 2008 The new pest risk analysis for $T$. indica, the cause of Karnal bunt of wheat, continues to support the quarantine status of the pathogen in Europe. Plant Pathology 57, 603-611.

Shakoor MA, Khan MA, Arif MJ, Javed N, Ilyas MB, Arshad M, Sahi ST. 2008 - Incidence of Karnal bunt disease of wheat in various districts of Punjab during 2006 and 2007 crop years. Pakistan Journal of Phytopathology 20, 190-194.

Sharma BK, Basandrai AK. 2000 - Effectiveness of some fungicides and bio-control agents for the management of Karnal bunt of wheat. Indian Journal of Mycology and Plant Pathology 30, $76-78$.

Sharma R, Kumar R. 2017 - Karnal bunt disease of wheat study from Jhunjhunu, Rajasthan. International Journal of Advance Research, Ideas and Innovations in Technology 3, 834-835.

Sharma RC, Sharma I, Kaur DJ, Bala R. 2011 - Disease free seed production of wheat in Punjab: Achievements. Journal of Wheat Research 3, 27-29.

Sharma RK, Babu KS, Chhokar RS, Sharma AK. 2004 -Effect of tillage on termites, weed incidence and productivity of spring wheat in rice-wheat system of North Western Indian plains. Crop Protection 23, 1049-1054.

Shewry PR. 2009 - Wheat. Journal of Experimental Botany 60, 1537-1553.

Singh DV, Gogoi R. 2011 - Karnal bunt of wheat (Triticum spp.) - a global scenario. Indian Journal of Agricultural Sciences 81, 3-14.

Singh S, Singh M, Taj G, Gupta S, Kumar A. 2012 - Development of surface plasmon resonance (SPR) based immuno-sensing system for detection of fungal teliospores of Karnal bunt ( $T$. indica), a quarantined disease of wheat. Journal of Biosensors and Bioelectronics 3, 1-8.

Stansbury CD, McKirdy SJ. 2002 - Forecasting climate suitability for Karnal bunt of wheat: a comparison of two meteorological methods. Australasian Plant Pathology 31, 81-92.

Stansbury CD, Pretorius ZA. 2001 - Modelling the potential distribution of Karnal bunt of wheat in South Africa. South African Journal of Plant and Soil 18, 159-168.

Stein JM, Maples HW, Rush CM. 2005 - Epidemiology of $T$. indica teliospores in regulated wheat fields in Texas. Plant Disease 89, 828-833.

Tan MK, Brennan JP, Wright D, Murray GM. 2010 - An enhanced protocol for the quarantine detection of $T$. indica and economic comparison with the current standard. Australasian Plant Pathology 39, 334-342. 
Tan MK, Brennan JP, Wright D, Murray GM. 2013 - A review of the methodology to detect and identify Karnal bunt - a serious biosecurity threat. Australasian Plant Pathology 42, 95-102.

Tan MK, Ghalayini A, Sharma I, Yi J, Shivas R, Priest M, Wright D. 2009 - A one-tube fluorescent assay for the quarantine detection and identification of $T$. indica and other grass bunts in wheat. Australasian Plant Pathology 38, 101-109.

Ullah HMZ, Haque MI, Rauf CA, Akhtar LH, Munir M. 2012 - Comparative virulence in isolates of $T$. indica and host resistance against Karnal bunt of wheat. Journal of Animal and Plant Sciences 22, 467-472.

Waalwijk C, van der Heide R, de Vries I, van der Lee T, Schoen C, Costrel-Decorainville, HaeuserHahn I, Kastelein P, Kohl J, Lonnet P, Demarquet T, Kema GHJ. 2004 - Quantitative detection of Fusarium species in wheat using TaqMan. European Journal of Plant Pathology 110, 481-494.

Wright D, Murray G, Brennan J. 2006 - Draft national contingency plan for Karnal bunt of wheat. Part I background and importance 1-79. 